\title{
Tourist support in Llanganuco Lagoon- Huascarán National Park, Perú
}

\section{Soportabilidad Turística en los sitios de visita de los senderos de la laguna Chinancocha-sector Llanganuco del Parque Nacional Huascarán, Perú}

\author{
Marcos Espinoza-Maguiña ${ }^{1}$, Henrry Garrido-Angulo² ${ }^{2}$, Jesús Espinola-Gonzales ${ }^{3}$ and Maximiliano Asís-López ${ }^{4 *}$ \\ 1 Doctor in Education, Academic Department of Tourism, Universidad Nacional Santiago Antúnez de Mayolo, Huaraz, Peru \\ 2 Master in science and engineering with a major in computing and computer science, Academic Department of Mathematics, Universidad Nacional Santiago Antúnez de Mayo- \\ lo, Huaraz, Peru, Huaraz, Peru \\ 3 Doctor in Mathematical Sciences, Academic Department of Mathematics, Universidad Carlos III de Madrid, Madrid, España \\ 4 Doctor of Science and Computer Engineering, Academic Department of Mathematics, Universidad Nacional Santiago Antúnez de Mayolo, Huaraz, Peru, Huaraz, Peru \\ * Corresponding author (E-mail corresponding author): maxasis06ஷagmail.com
}

\section{ABSTRACT}

The objective is to determine the tourist supportability at the visit sites of $A$ and $B$ transects of Chinancocha Lagoon, in the district and province of Yungay-Ancash region. The logical historical method was used, the deductive inductive method and the observation were also used; as techniques the bibliographic review, the documentary analysis, as well as the criteria of the specialists to validate the conflicts of use-resources and to select the variables of the field of action were used. We made a direct observation in situ with photographic records, an interview guide, and a questionnaire. Load capacity was determined at three levels: (CCF) of 1969 visitors, (CCR) of 1655 visitors and (CCE) of 1208 visitors at a certain time of use at Chinancocha Lagoon, considering an average of 1 to 1.40 effective hours of visit per day.

Keywords: touristic support, visit sites, trail, visitor, Huascaran National Park

\section{RESUMEN}

El objetivo es determinar la soportabilidad turística en los sitios de visita de los transectos A y B de la Laguna de Chinancocha, del distrito y provincia de Yungay- región Áncash. Se utilizó el método histórico lógico, el método inductivo deductivo y la observación; como técnicas se emplearon la revisión bibliográfica, análisis documental, así como el criterio de los especialistas para validar los conflictos de uso-recursos y para seleccionar las variables del campo de acción. Se realizó la observación directa en campo con registro fotográfico, una guía de entrevista, y un cuestionario. Se determinó la Capacidad de carga en tres niveles: (CCF) de 1969 visitantes, (CCR) de 1655 visitantes y la (CCE) de 1208 visitantes en un determinado tiempo de uso en la Laguna de Chinancocha, considerando un promedio de 1 a 1.40 horas efectivas de visita al día.

Palabras clave: soportabilidad turística, sitios de visita, sendero, visitante, Parque Nacional Huascarán 


\section{INTRODUCTION}

Huascarán National Park (PNH) was created by supreme decree No. 0622-75-AG on July 1st, 1975. PNH was recognized as Biosphere Reserve by UNESCO on March 1st, 1977; and as a Natural Heritage of Humanity in December 1985 .

Inside the National Park there are only 50 small human settlements with 548 inhabitants (on average 11 people per settlement, they are located in the buffer zone and which have been organized by sectors and the peasant community "Unidos Venceremos" is one of those sectors, whose members organize the minor tourist activities within A trail of Chinancocha lagoon, which is located in the tourism and recreation use zone of Huascarán National Park. A physical infrastructure has been implemented there for the administrative management and the services offered; an entry trail via an affirmed road Vehicle control post (PCV), Visitor room, SV) signaling and signaling (SS) Toilet facilities (SS. HH) 2 piers, (2E) sales areas of handicrafts and food, (AVAA) 2 walking trails, (2S) and vehicular parking areas (AEV), sector that is controlled by the AASAM, and CUPS of the co Peasant communities, made up of 5 park rangers, who make 6 patrols per month (routine and special).

The tourist load capacity is a specific modality of environmental load capacity, which is defined as "the maximum population that can support indefinitely a certain habitat without permanently damaging the productivity of the ecosystem on which that population depends" (Ceballos-Lascuráin, 1996).

The determination of tourist carrying capacity constitutes a planning tool that allows to obtain an approximation to the intensity of use of the areas destined for public use, so it supports and requires management decisions (Cifuentes 1992, Acevedo 1997). The calculation is made through a complex process in which a series of ecological, physical, social, economic and cultural factors must be considered (Moore, 1993). The methodology for the calculation of the tourist load capacity has been applied in Costa Rica (Cifuentes et al; 1999, Rodríguez, 1992, Acevedo 1997, Fundación Neotrópica 1992, Bajaña 1998), Ecuador (Cayot et al; 1996), and in Brazil (Mitraud, 1997).

The problem of calculating tourist cargo capacity is com- plex, despite having reliable, current and relevant information on the conditions and quality of the services in which tourism activities are carried out, apart from the impacts (environmental, social, cultural and economic) that is still causing. Based on the available information, the decisions to be made allow the prevention, limits, compliance with the regulations, (tourist use regulations, statute, contracts) determining standards or other instruments, which must be implemented, ensuring that the negative impacts of tourism are not severe or irreversible.

The tourist activity in the $\mathrm{PNH}$ is transversal to many activities and aspects of the environmental, social, economic and tourist reality of the region; It involves a multitude of public actors such as the Regional Directorate of Tourism (DIRCETUR) and private, many of them with conflicting interests, coming to have implications not only within the ANP, but in its immediate environment and region. The tourist activity is carried out in an unplanned way, management with little participation of the actors involved, and strengthened with problems of informality by the tour operators. In this context and in view of the many factors that tourism management requires to intervene, the study provides only in the areas of intervention.

A novel model with the application of images to establish the collective imaginary of the tourist space, terrestrial links and marine evaluation and includes the perception of the local community, which allows significant changes in the way of measuring and interpreting tourist impacts and the ability to load of natural areas of protected areas. However, the difficulties inherent in the conservation of ecosystems, social interests and tourist activities are recognized. For this research, the process of consulting with local users with extensive experience and establishing mathematical averages was the best approach for the absence of information due to the need to operationalize conservation strategies (Segrado, Gonzales, Arroyo \& Quiroga, 2017).

The Effective Load Capacity (CCE), that is, the maximum number of visits that the area can support to carry out this activity without any deterioration of the ecosystem, is 120 visitors per day (Crispin, Berovidez, Marín, García \& Fernández-Truan, 2017). 
The Pasochoa Wildlife Refuge is a significant area for conservation, it has great tourist potential due to the natural resource that allows to offer alternatives for nature, adventure or high mountain tourism, with the necessary infrastructure. The protected area receives a constant influx of national and foreign tourists mostly from the province of Pichincha, due to the proximity of the metropolitan district of Quito to the Mejía canton, easy access and the dissemination of free admission to the protected areas (Sánchez, 2017).

In the proposal of measurement of load capacity it makes use of variables established in existing methodologies, and incorporates new variables and correction factors in the environmental, social and economic dimensions, in order to achieve a more comprehensive analysis of the territory under study. Regarding the existing methodologies for measuring the load capacity, it is clear that from the theoretical point of view there is no consensus on the variables to be used. In this sense, the state of the art allowed to determine that they presented weaknesses and weaknesses that could be adjusted and improved according to the conditions of the territory to be measured. In this way, the research sought to approximate a measurement based on true and justifiable data (Rodríguez, 2018).

The load capacity of the colonial trails evidences the potential that it has in the Chicaque Natural Park to increase its tourist offer, mainly due to the management that the reserve has developed in the services it offers to visitors, being the handling capacity the factor that more positive influence on the number of visitors allowed. Based on the carrying capacity, the natural park can offer ecological tourism with greater confidence and control, using these results as an instrument to promote the sustainable management of tourism activities carried out in the protected area (Barbosa and Saénz, 2017).

The tourist carrying capacity on Palomino beach obtained a value of $36.6 \mathrm{~m} 2$ / hab, which is the maximum ecological load capacity, thus determining that the beach can receive a total of 2627 inhabitants per month, a value that has not yet been exceeded touristically. The tourist load capacity is directly conditioned by the ecological load capacity, since this is prevailing befo- re the other components (Hernández and Montaño, 2017).

The objectives that were set for the study were as a general objective: to determine the portability of the visit sites of the natural area of Chinancocha lagoon and, as well as, specific objectives: Describe the transects $A$ and $B$, in space and time of the sites of visiting Chinancocha Lagoon, identifying the minor tourist activities organized in time and space within Chinancocha Lagoon, and identifying the satisfaction of the visiting sites of Chinancocha Lagoon.

\section{METHODOLOGY}

For the registration and collection of information, it was done taking into account the stages of the research project. The logical historical method was used for the analysis of the existing load capacity methodologies and to characterize the different stages of the study; the deductive inductive method for the phenomenal analysis and interpretation of the study and the Observation. As techniques, the literature review, documentary analysis, as well as the criteria of the specialists were used to validate the use-resource conflicts and to select the variables that allow determining the field of action and decisions were made for a management improvement plan tour; using participatory work techniques, visits, participatory observation that allowed to reach consensus. Additionally, matrices were developed at each reference point in the visiting sites. Using GPS-Garmin field equipment for the registration of waypoints and tracks, as well as $50 \mathrm{~m}$ metal Wincha.

The facilities capacity and spaces enabled for visitors for an average of $2 \mathrm{hr}$ and 30 min can reach 1969 people according to the results. And considering that the dynamics of visitors are characterized by having up to three schedules or flows of visitors (from $10 \mathrm{am}, 1 \mathrm{pm}$ and $3 \mathrm{pm}$ ), in that sense, the physical load capacity of the visit sites defined as "The number maximum of people who can visit Chinancocha Lagoon at the same time, without causing significant deterioration or destruction of the landscape environment or a considerable decrease in the level of visitor satisfaction" would be 1969 visitors per day. 
Table 1: Capacity limitation of main instalations and infraestructure of view sites

\begin{tabular}{|c|c|c|c|}
\hline $\begin{array}{l}\text { Infrastructure } \\
\text { type }\end{array}$ & $\begin{array}{l}\text { Capacity } \\
\text { limitation } \\
\text { established(*) }\end{array}$ & $\begin{array}{l}\text { Current } \\
\text { capacity } \\
\text { limitation }\end{array}$ & $\begin{array}{l}\text { Estimated } \\
\text { lifetime }\end{array}$ \\
\hline $\begin{array}{l}\text { Control post } \\
\text { Visitor } \\
\text { interpretation } \\
\text { room Craft area } \\
\text { Pier } 1-\mathrm{N}^{\circ} \text { of } \\
\text { people per Boat }\end{array}$ & $\begin{array}{l}12 \text { people } \\
25 \text { people } \\
50 \text { people } \\
100 \text { people } \\
\text { (10 people } x \\
10 \text { boats). }\end{array}$ & $\begin{array}{l}\text { Null } \\
10 \text { people } \\
80 \text { people } \\
\text { Low } \\
\text { season } 40 \\
\text { people } \\
\text { Peak } \\
\text { season } 100 \\
\text { people }\end{array}$ & $\begin{array}{l}15 \text { years } \\
15 \text { years } \\
10 \text { years } \\
5 \text { years }\end{array}$ \\
\hline
\end{tabular}

Interpretation.- Total bearing capacity 187 people

(*) Capacity limitation is based on the plans, maps and indicators set by the $\mathrm{PNH}$ headquarters

Table 2: Physical load capacity of visitors in a day at Chinancocha lagoon

\begin{tabular}{llll}
\hline Infraestructure & $\begin{array}{l}\text { Surface } \\
(\mathbf{m} 2)\end{array}$ & $\begin{array}{l}\text { Maximum } \\
\text { stocking } \\
\text { density / m2 }\end{array}$ & $\begin{array}{l}\text { Capacity } \\
\text { limitation for } \\
\text { visitors }\end{array}$ \\
\hline Trails & 656.4 & 1 & 656 \\
Resting areas & 504.0 & 2 & 336 \\
$\begin{array}{l}\text { Photography } \\
\text { areas }\end{array}$ & 1579.0 & 2 & 790 \\
Facilities' & & & 187 \\
capacity & & & 1969 Visitors \\
\hline Total & & &
\end{tabular}

Visiting time approx. 2.5 to 4 hrs long

A single Schedule they visit throughout the day

Maximum Physical Load Capacity of visitors per day at Llanganuco sector would be:1 969 visitors

The facilities ' capacity and spaces enabled for visitors for an average of $2 \mathrm{hr}$ and 30 min can reach 1969 people according to the results. And considering that the dynamics of visitors are characterized by having up to three sche- dules or flows of visitors (from $10 \mathrm{am}, 1 \mathrm{pm}$ and $3 \mathrm{pm}$ ), in that sense, the physical load capacity of the visit sites defined as "The number maximum of people who can visit Chinancocha Lagoon at the same time, without causing significant deterioration or destruction of the landscape environment or a considerable decrease in the level of visitor satisfaction "would be 1969 visitors per day.

Table 3: Actual load capacity: Conservation factor of Chinancocha lagoon

\begin{tabular}{lllll}
\hline Items evaluated & $\begin{array}{l}\text { Assigned } \\
\text { values }\end{array}$ & $\begin{array}{l}\text { Tabula- } \\
\text { tion }\end{array}$ & Total \\
\hline $\begin{array}{lllllll}0 & 1 & 2 & 3 & 4\end{array}$ \\
\hline
\end{tabular}

Waste sighted on shore $\mathrm{X}$ and body of water (food waste, plastics, candy wrappers, ice cream).

Clandestine roads to the $\mathrm{X} \quad 1$ lagoon (excessive growth of the totora).

$\begin{array}{lll}\text { Assessment of } & 1 / 3 & 0.33\end{array}$ conservation status: Lagoon

The results obtained show with influence lines for the point of a low level regarding to the conservation state of Chinancocha lagoon.

Table 4: Current load capacity: state conservation factor of the trails of the visiting sites

\begin{tabular}{|c|c|c|}
\hline Items evaluated & $\begin{array}{l}\text { Assigned } \\
\text { values }\end{array}$ & $\begin{array}{l}\text { Tabula- Total } \\
\text { tion }\end{array}$ \\
\hline & $\begin{array}{llll}0 & 1 & 2 & 3\end{array}$ & \\
\hline
\end{tabular}

Throwing waste into the forest (food waste, $\quad \mathrm{X} \quad 1$ plastics, wraps)

Marks and / or uproot trees, plants and stones

Generate other clandestine trails (clandestine baths, $x$ 2 private photographs, etc.) 
In summary, it is observed that the impact generated by visitors on the trails has a medium level, evidencing environmental attitudes that are not favorable to their conservation by visitors.

It is observed that the infrastructure is in conditions on a regular level among these highlights: the vehicle control post at the entrance, the interpretive room, the jetty, signage and trails are accessible.
The toilet facilities, the parking area, the food sales sector and the craft sales room are at a bad level, they need to make improvements.

As for the equipment; it is observed that the equipment to fulfill the functions of control of displacements and for the maintenance of trails, squares or stairs is limited.

Figure 1. Satisfaction and y expectations level of minor tourist activities of visitors

Table 5 Effective loading capacity in the visit sites of Chinancocha lagoon

\begin{tabular}{|c|c|c|c|c|c|c|}
\hline Infraestructure & $\begin{array}{l}\text { Current } \\
\text { amount (A) }\end{array}$ & $\begin{array}{l}\text { Maintenance } \\
\text { level ( } 0 \text { a } 5)\end{array}$ & $\begin{array}{l}\text { Functionality } \\
\text { level ( } 0 \text { a } 5)\end{array}$ & $\begin{array}{l}\text { Estimated } \\
\text { lifetime } \\
\text { (years) }\end{array}$ & Qualification & Weighing/12 \\
\hline Entry - control post & 1 & 3 & 1 & 5 & 0.8 & 0.06 \\
\hline Visitor Interpretation room & 1 & 3 & 1 & 4 & 1 & 0.08 \\
\hline Information panels & 3 & 4 & 3 & 5 & 1.4 & 0.11 \\
\hline Restaurant area & 1 & 2 & 3 & 4 & 1.25 & 0.10 \\
\hline Craft area & 1 & 3 & 2 & 5 & 1 & 0.08 \\
\hline Boats & 10 & 2 & 4 & 4 & 1.5 & 0.12 \\
\hline Piers & 2 & 3 & 5 & 5 & 1.6 & 0.13 \\
\hline Rest benches & 1 & 2 & 3 & 3 & 1.6 & 0.13 \\
\hline Toilet facilities (SSHH) & 2 & 2 & 4 & 3 & 2 & 0.16 \\
\hline Handrails & 2 & 3 & 3 & 5 & 1.2 & 0.1 \\
\hline Parking areas & 3 & 2 & 4 & 3 & 2 & 0.20 \\
\hline Average & & & & & & 1.1 \\
\hline
\end{tabular}

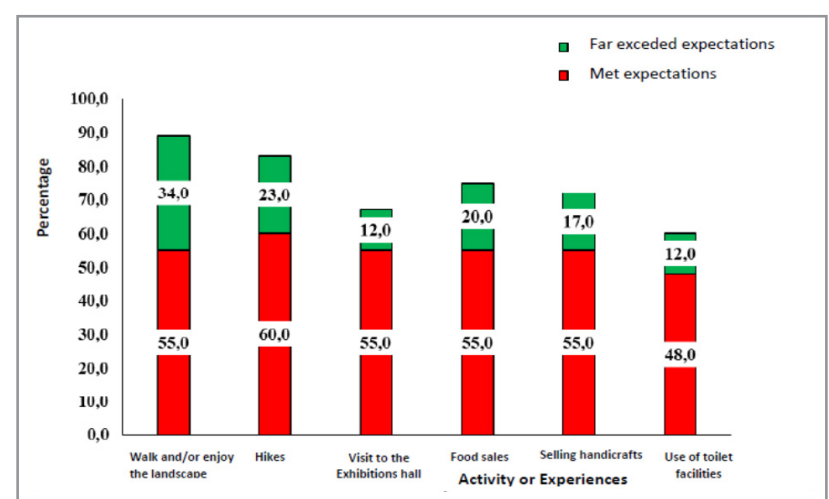

In summary, the minor tourist activities that complement the tourist visit of Chinancocha Lagoon exceed the level of expectations by approximately $70 \%$; that in general terms is due to the level of conservation of the space (trails and lagoon), to the dynamics of visit that has been established by custom (that is to say at the discretion of the tourism companies and the headquarters of the Huascarán National Park) that in Much of the year does not generate congestion except 5 to 8 days a year (national holidays and easter).

\section{DISCUSSION}

The calculation of load capacity will be based on the methodology of Cifuentes (1992), which seeks to establish the maximum number of visits that a protected area can receive based on the physical, biological and management conditions that occur in the area at the time of the study. The process consists of three levels: calculation of physical load capacity (CCF), calculation of real load capacity (CCR) and calculation of effective capacity (CCE) have a relationship that can be represented as $\mathrm{CCF} \geq \mathrm{CCR} \geq \mathrm{CCE}$. 
The calculations are based on the following assumptions that can be adapted to specific conditions: One-way visitor flow on both trails, a person normally requires $1 \mathrm{~m} 2$ of space to move freely. In the case of trails, it translates into 1 linear meter, provided that the width of the trail is less than $2 \mathrm{~m}$., Time needed for a visit to each trail: $1.5 \mathrm{hr}$. And the visiting hours: 8:00 a.m. to 4:00 p.m. that is, with a duration of 8 hours per day.

The estimation of the real load capacity, the formula is very simple, the real load capacity (CCF) is multiplied by the weighted average correction factor (FCpp); so CCF $\mathrm{x}$ FCpp = actual load capacity; replacing $1969.9 \times 0.84$ gives us equal to 1654.7 visitors, concluding that the actual carrying capacity is 1655 visitors to Chinancocha lagoon visiting sites for one day.

And according to Soria-Díaz and Soria-Solano (2015) argue that the correction factors (FC) and the handling capacity $(\mathrm{CM})$ have an influence on the determination of the (CCR) and (CCE), respectively by the particularities of each site of visit and also supported by Barbosa and Saénz (2017) that the ability to manage is the factor that positively influences the number of visitors allowed.

Regarding to the estimation of the effective load capacity: the management factor would be $(0.89+1.1+0.21)$ $/ 3=0.73$. To sum up, the effective load capacity (CCE) is the result of multiplying the actual load capacity (CCR) by the correction factor 0.73; then the effective load capacity $=1654.7 \times 0.73=1207.9$. concluding that the effective loading capacity of the trails of Chinancocha lagoon is 1208 visitors at a certain time. This is the number of visitors, at a given time (considering 1 to 1.40 hours of visit per day), however, this number could be modified as soon as specific visiting hours are implemented and it is considered to overcome the limitations identified.

The results obtained on the tourist supportability in the sites of visit and of the evaluated trails serve as scientific and administrative contribution to the Headquarters and to the improvement of the management of the visitor and serve as a support for the tourist plan and recreational use of the $\mathrm{PNH}$.

\section{CONCLUSIONS}

The methodological processes of the study were ade- quately fulfilled, taking as reference the transects $A$ and B, determining the Physical Load Capacity (CCF) of 1969 visitors, the Real Load Capacity (CCR) of 1655 visitors and the Capacity of Effective Load (CCE) of 1208 visitors at a certain time of use in Chinancocha Lagoon, considering an average of 1 to 1.40 effective hours of visit per day

The transect A, includes a total area of $378 \mathrm{~m} 2$, with a duration of the walk from the parking lot to the main jetty with an estimated time of 5 to 10 min., Observing that most of the visitors take the first photographs from the lagoon and surrounding landscapes.

Transect B, includes a total area of $278.4 \mathrm{~m} 2$, with a duration of walk through the forest from the main jetty to the second jetty, with an estimated time of 13 to 25 min., Where the forest takes pictures of queñuas and the other space of the lagoon; as well as observing a rest area.

In transect $A$, the various minor activities are identified, such as: boat ride with a duration from 10 to 20 minutes, with a maximum capacity of 100 visitors, observing that they only visit the third part from the lagoon and in the high season the travel time is reduced due to high demand.

Regarding to the sale of handicrafts, the duration of the visit is from 8 to 15 minutes, with a capacity limitation of 80 visitors, where utilities are sold (hats, gloves, scarves, sweaters, among others), observing a stylized craft.

The museum exhibition duration of visit is from 8 to 15 min. with a capacity limitation of 25 visitors, observing in that way that the room lacks lighting, interpretation and museum design, therefore, it itself does not create motivation to be visited.

And the duration of the selling food process in the region and teas like muña, white oregano and cedron are: from 30 to 60 min., As well as, the use of toilet facilites is 5 to 10 min.

It is concluded that $90 \%$ of visitors consider that their visit is at the level of their expectations and sometimes exceeds them. This is due to the degree of conservation of the environment (forests, and mainly lagoon) which according to the analysis is quite acceptable. The feeling of being close to the snowy mountains and sailing in Chinancocha lagoon is a unique experience for visitors. 
Three correlative scenarios were identified which are caIled: "Take control", "Establish a management model" and "Consolidate the model under permanent evaluation". It will contribute to a comprehensive strengthening of the level of visitors management, control actions and mainly the conservation of Llanganuco sector.

\section{ACKNOWLEDGEMENTS}

To the General Research Office of UNASAM, Headquarters and Park Rangers at HNP, the director of DIRCETUR and the members of the United Community will win.

\section{REFERENCES}

Acevedo Ejzman, M. (1997). Determinación de la capacidad de carga turística en dos sitios de visita del Refugio de Vida Silvestre La Marta, e identificación de su punto de equilibrio financiero. Universidad Latinoamericana de Ciencia y Tecnología. San José, Costa Rica.

Bajaña, D. (1998). Adaptación y Validación de Procedimientos para Evaluar la Capacidad De Carga Turistica En El Parque Nacional Corcovado, Costa Rica. Turrialba

Barbosa, y Saénz (2017). Diseño de la interpretación ambiental y análisis de capacidad de carga turística del sendero colonial del Parque Natural Chicaque (San Antonio del Tequendama-Cundinamarca. Estudio de la Universidad Distrital Francisco José De Caldas, Facultad del Medio Ambiente y Recursos Naturales, Proyecto Curricular de Ingeniería Forestal Bogotá, Colombia.

Cayot, L., Amador, E., Cifuentes, M., Eliécer, C., \& Cruz, F. (1996). Determinación de la Capacidad de Carga Turística en los Sitios de Visita del Parque Nacional Galápagos. Puerto Ayora.

Crispin Castellanos, D., Berovidez Álvarez, V., Marín Clemente, J., García Ucha, F., \& Fernández-Truan, J. (2017). Límites en la capacidad de carga de visitantes de ecoturismo en Punta del Este, Isla Juventud (Cuba). Investigaciones Turísticas, 0(13), 96-113. doi:https://doi.org/10.14198/ INTURI2017.13.05
Cifuentes, M. (1992). Determinación de capacidad de carga turística en áreas protegidas. CATIE. Serie Técnica. Informe Técnico No. 194. Turrialba, Costa Rica.

Cifuentes, M., Mezquita, C., Méndez, J., Morales, M., Aguilar, N. Cancino, D., Gallo, M., Jolón, M., Ramírez, C., Ribeiro. N., Sandoval, E. \& Turcios. M. (1999). Capacidad de Carga Turística de las Áreas de Uso Público del Monumento Nacional Guayabo, Costa Rica. Fondo Mundial para la Naturaleza (WWF), Centro Agronómico Tropical de Investigación y Enseñanza (CATIE). 75p.

Crispin, Berovidez , Marín, García, \& Fernández, J. (2017). Límites en la capacidad de carga de visitantes de ecoturismo en Punta del Este, Isla de la Juventud (Cuba). It was obtained from file:///E:/ TESIS/Capacidad\%20de\%20carga/Investigaciones-Turisticas_13_05.pdf

Ceballos-Lascuráin, H. (1996). Tourism, ecotourism and protected areas. IV. Congreso Mundial sobre Parques Nacionales y Áreas Protegidas. IUCN.

Fundación Neotrópica. (1992). Análisis de Capacidad de Carga para Visitación en las Areas Silvestres Protegidas de Costa Rica. Centro de Estudios Ambientales y Políticas. Fundación Neotrópica. San José, Costa Rica.

Hernández y Montaño (2017). Determinación de la capacidad de carga turística en la playa de Palomino, Municipio de Dibulla, Guajira. It was obtained from https://repository.usta.edu.co/bitstream/ handle/11634/16721/2019leonardohernandez. pdf?sequence $=3 \&$ isAllowed $=y$

Mitraud, Sylvia (1997). Determinación de la Capacidad de Carga y Sistema de Monitoreo del Impacto de la Visitación. Proyecto de Desarrollo de Senderos Interpretativos del Parque Nacional Marino de Fernando de Noroña. Brasilia, Brasil.

Moore, A. (1993). Manual para la capacitación del personal de áreas protegidas. National Park Service. USA. Vol 2.

Segrado Pavón, R. G., Gonzales Baca, C. A., Arroyo, A. L., \& Quiroga García, B. A. (2017). Capacidad de 
carga turística y aprovechamiento sustentable de Áreas Naturales Protegidas. It was obtained from file:///E:/TESIS/Capacidad\%20de\%20carga/capacidad\%20de\%20carga\%20y\%20aprovechamiento\%20sustentable.pdf

Soria-Díaz, H.F. y Soria-Solano, B. (2015). Determinación de la capacidad de carga turística en los sitios de visita de la Reserva Nacional Allpahuayo-Mishana, Loreto, Perú. Ciencia amazónica (lquitos), 5 (1), 25-34.

Rodríguez V., J.E. (1992). Determinación de Capacidad de Carga Turística para el Parque Nacional Manuel Antonio. Tesis MSc. Turrialba, Costa Rica. CATIE. 183 p.
Rodríguez, S. (2018). Propuesta metodológica para le medición de la capacidad de carga turística del Haynes Cay en San Andrés Isla. Tesis para optar el título de Magister de la Universidad Externado de Colombia de la Facultad de Administración de Empresas Turísticas y Hoteleras.

Sánchez, E. (2017). Estudio de capacidad de carga de los senderos turísticos en el refugio de vida silvestre Pasochoa, provincia de Pichincha. Tesis para optar el título de Ingeniero en Administración de empresas turísticas y conservación ambiental de la Universidad Tecnológica Equinoccial de la Facultad de Hospitalidad y Servicios. 